\title{
Analysis of Factors Determining the Demand for Water: A Case Study of Sabié Administrative Post, Moamba District, Mozambique
}

\author{
Hélder António Manjate ${ }^{1}$ and João Enganado Mutondo ${ }^{2}$ \\ 1. Faculty of Agricultural and Forestry Engineering at Zambeze University, P.O. Box 49, Mocuba District, Zambézia Province, Mozambique \\ 2. Faculty of Agronomy and Forestry Engineering at Eduardo Mondlane University, P.O. Box 257, Maputo, Mozambique
}

\begin{abstract}
Water is an important resource for human being. However, it has been increasingly becoming the limited resource. Therefore, the debate of water issues has been centered in mechanisms to implement sustainable water management. Hence, understanding the determinants of water demand might help design appropriate water management policies, however, they are not known in Mozambique. Due to the lack of knowledge about the determinants of water demand in Mozambique in general and in Sabié in particular, the present study was conducted to analyse the factors determining the water demand for irrigation and domestic use using a linear regression model and travel cost method, respectively. The results show that an increase in $1 \mathrm{~h}$ of irrigation time increases the quantity demanded of irrigation water by $362.04 \mathrm{~m}^{3}$ and an increase in one irrigation per week increases the quantity demanded of irrigation water by $1,065.61 \mathrm{~m}^{3}$. Additionally, the results show that an increase in $1 \%$ of time spent in water collection decreases the number of trips by $0.3 \%$ and an increase in $1 \%$ in the number of household members involved in water collection decreases the number of the water collection trips by $0.23 \%$. Household having private taps have less number of trips collecting water compared to those collecting water from public taps and boreholes as well as rivers. Therefore, the water demand for irrigation is determined by time spent for irrigation per day and the number of irrigations per week, and water demand for domestic use is determined by time spent for water collection, number of household members involved in water collection, the volumes of the containers used to collect water, the number of containers used to collect water, the quantity of water consumed by the household as well as the main source of water (river, boreholes and public tap).
\end{abstract}

Key words: Domestic use, irrigation use, water demand.

\section{Introduction}

Water is an important resource for human being. However, it has been increasingly becoming the limited resource. For example, in 2000, about 250 million people in 26 countries faced chronic limitation in water supply, and this number had been projected to increase to 3,000 million people in 52 countries by 2020 [1]. Additionally, according to Seckler et al. [2], the quantity of water available yearly for each person decreased from $12,900 \mathrm{~m}^{3}$ in 1970 to $5,100 \mathrm{~m}^{3}$ in 2005 , with an decrease of $60.5 \%$. The rapid increase in water demand is also true in Sabié. Water supply in

Corresponding author: João Enganado Mutondo, assistant professor, research field: agrarian economy.
Sabié is mainly dependent on Inkomati river basin. According to Vas and Zaag [3], the basin's average surface water availability is 171 million $\mathrm{m}^{3}$ yearly. Competition over water is real, and water abstractions are fast approaching the limits of sustainability. This scenario is mainly due to the establishment of new agricultural enterprises in the basin, such as Indian Farm with about 7,000 ha and COFAMOSA association with $29,000 \mathrm{ha}^{1}$ in Sabié region of Moamba district, the expansion of production area of Xinavane Sugar Company by 3,000 ha in Magude district, and the need to increase water supply for

\footnotetext{
${ }^{1}$ According to ARA-Sul officials, due to limited water supply, the current available water can irrigate only 10,000 ha of COFAMOSA association.
} 
Maputo city coupled with the inexistence of adequate water storage infrastructures.

Given the rapid increase in water demand in Inkomati, the debate of water issues at basin level has been centered in mechanisms to implement sustainable water management. Martins and Fortunato [4] report that one of the mechanisms to improve water management is to use price policies through charging water demand and not "non price policy" through monitoring water use. However, the designing of appropriate mechanisms to improve water management is in part depending on knowing which factors determine the demand for water in the basin.

Previous studies on water demand for irrigation focus on technical efficiency of water use. Speelman et al. [5] used Tobit model to analyze the determinants of technical efficiency of water demand for irrigation. The results of the study showed that technical efficiency in water demand for irrigation reduces with an increase in irrigated area, and flooding irrigation is less efficient compared to other types of irrigation (aspersion and dropwise). Mahdi et al. [6] used Tobit model to evaluate the technical efficiency of water demand for irrigation. The results also showed that technical efficiency increases with an increase in irrigated area, which supports that large farmers are more efficient in water use compared to small farmers. Additionally, Chebil et al. [7] using the same methodology found that technical efficiency increases for producer having access to extension services. The experience of the farmer was also important factor determining technical water use efficiency [8].

The majority of studies analyzing water demand for domestic use focus on demand of tap water in developed countries, where data on quantity demanded and the paid prices are available. However, in rural areas of developing countries, like Mozambique, data on water quantity demanded and prices are not available, and in many cases, consumers do not pay for water use and if there is a fee, it is a fixed fee. Therefore, empirical studies of water demand for domestic uses in developing countries are limited [9]. The majority of the studies that attempted to analyze water demand for domestic use in rural areas of developing countries used contingent evaluation to determine the consumers' willingness to pay for having tap water in the house $[10,11]$, and hedonic analysis to determine the value of new tap water connection by observing the prices of the houses $[12,13]$.

Other authors used travel cost method in evaluating the water demand for domestic use [10, 14, 15]. The results of these studies showed that an increase of $1 \%$ in opportunity cost reduces the number of travels to fetch water by $4 \%$ if the source of water is public tap, and $10 \%$ if the source of water is river. Banda et al. [14] and Kanyota [16] found that the willingness to pay to install a canalized water system at home is about in 27.67 rands/month in South Africa. Farolfi et al. [17] in their study revealed that willingness to pay for the improvement of water supply services increases with an increase in household income. The authors also found that as the number of hours needed to fetch water increases, the willingness to pay for improving water services also increases.

Although understanding the determinants of water demand might help designing appropriate water management policies, they are not known in Mozambique. Studies on water management in Mozambique focus on supply side and mainly hydraulic and infrastructures as well as organizational set up of institutions managing water resources [18-22]. Therefore, there is a lack of knowledge about the determinants of water demand in Mozambique in general and in Sabié in particular. Hence, the present study aimed to analyze the factors determining the water demand for irrigation and domestic use.

\section{Methodology}

\subsection{Study Location}

The study was conducted in Administrative Post of Sábie, located in Moamba district, Mozambique. The 
Moamba district is situated at north of Maputo province, $110 \mathrm{~km}$ from the Maputo city, as shown in Fig. 1.

\subsection{Procedures}

\subsubsection{Water Demand for Irrigation}

The demand for irrigation water is derived using production theory (profit maximization), since water is input in crop production process as shown in Eq. (1):

$$
\pi(p, w)=\max _{x \geq 0}\{p f(x)-w x\}
$$

where, $p$ is a vector of the price of the produced crop; $w$ is a vector of prices of inputs used in production process; $x$ is a vector of quantities of inputs used in production process; $f(x)$ represents the production function. Eq. (1) can also be expressed in differentiating form as Eq. (2):

$$
\frac{\partial_{\pi}}{\partial_{w}}=-x(p, w)
$$

From Eq. (2), it can be seen that the demand for input (irrigation water) is in function of the vector of the prices of the produced goods, as well as the vector of the prices of inputs used in production process. Besides the variables resulting from theoretical derivation, it was reported in Refs. [5-8, 23] that demand for irrigation water is a function of the area to be irrigated, type of crop being irrigated, production season, type of irrigation, time spent irrigating the crop and type of production system (monoculture vs. crop mixing). Therefore, to analyze the determinants of irrigation water demand, the ordinary least square through a linear regression was used as shown in Eq. (3):

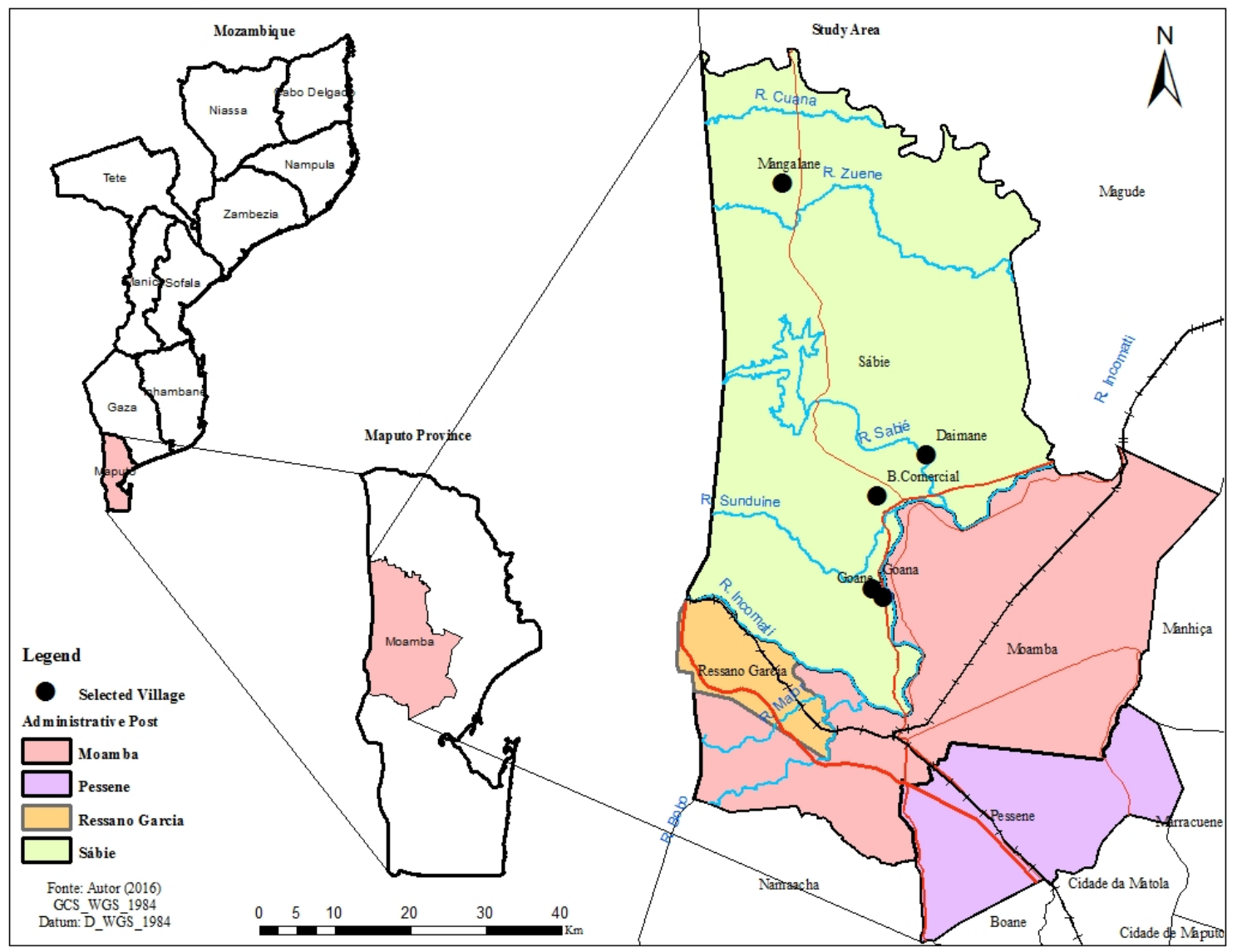

Fig. 1 Study location in Moamba district, Mozambique. 


$$
Y_{i}=a_{0}+a X_{i}+\varepsilon_{i}
$$

where, $Y_{i}$ is the quantity demanded of irrigation water by producer $i$. The quantity demanded of irrigation water is calculated using the formula proposed by Bress which is cited by Luís [24], as Eq. (4):

$$
\varphi=\left(\frac{D}{K}\right)^{2}
$$

where, $\varphi$ is the quantity demanded of irrigation water $\left(\mathrm{m}^{3} / \mathrm{s}\right) . K$ is Bress coefficient, which is equal to 0.9. $D$ is the diameter of the discharge pipe (m). $X_{i}$ is the vector of independent variables, including irrigated area (ha); number of irrigations per week; type of the crop composed of five dummy variables: $D_{1}=1$ if the produced crop is tomato and 0 otherwise, $D_{2}=1$ if the produced crop is cabbage and 0 otherwise, $D_{3}=1$ if the produced crop is green beans and 0 otherwise, $D_{4}$ $=1$ if the produced crop is cucumber and 0 otherwise, $D_{5}=1$ if the produced crop is pepper and 0 otherwise $^{2}$; the type of irrigation, which is equal to 1 if the type of irrigation is flooding and 0 otherwise; the duration of each irrigation (h); the production system, which is equal to 1 if it is monoculture and 0 otherwise. $\alpha$ and $\alpha_{0}$ are parameters to be estimated. $\varepsilon_{i}$ is the error term, which follows normal distribution with zero mean and constant variance.

Although the theoretical derivation shows that the demand for irrigation water is a function of output and input prices, these variables were not included in Eq. (3) above. It is important to note that producers in Sabié produce different crops, thus making it difficult to have a series of price data to be used. And as a proxy of crop price, a dummy variable was used indicating the type of the produced crops. Additionally, given that producers do not pay for water use, the price of fuel used to pump the water was considered to be used as a proxy of water price. However, this variable was dropped, as it did not vary among producers. The lack of including of output and

\footnotetext{
${ }^{2}$ The category of other remaining crops served as reference of the five dummies variables described above.
}

input prices in modeling demand for irrigation water is a limitation of the present study.

According to Refs. [5-8, 23], the positive relationships are expected between quantity demanded of irrigation water with the following variables: irrigated area, number of irrigations per week, duration of each irrigation, type of irrigation and production system. The relationship between the quantity demanded of irrigation water and the type of crop is mixed, as each plant has its own water requirement. However, crops requiring more water are expected to demand higher quantities of water compared to the crops requiring less water.

\subsubsection{Water Demand for Domestic Use}

African rural households demand water from different sources. These sources can be rivers, public water suppliers, such as tap and boreholes. And in many cases, rural households do not pay for the water demanded for domestic use, mainly if the water is from rivers and community boreholes and taps, except few arrangements where households pay a fixed fee per month for demanding water from public sources. For the water sources where fees are charged, they are not readily available or the information is not enough to support the analysis. Given the absence of price data for water in African rural settings, researchers have estimated water demand for domestic uses using non price evaluation methods. Therefore, in this study, the estimation of water demand for domestic use followed the travel cost method as suggested by Banda et al. [25] using a poison distribution. Detail of the travel cost method applied to water demand is presented in Ref. [25]. In this model, water demand is specified as given in Eq. (5):

$$
Y_{i j}=\delta_{0}+\delta X_{i j}+\varepsilon_{i j}
$$

where, $\delta$ are $\delta_{0}$ are parameters to be estimated. $\varepsilon_{i j}$ is the error term. $Y_{i j}$ is the number of trips to fetch water made by member $j$ who belongs to household $i . X_{i j}$ represents a vector of explanatory variables, including: 
(1) The number of household member $\left(n_{1}\right)$;

(2) The household income $\left(n_{2}\right)$. This variable takes three categories of 500.00-2,500.00, 2,501.00-5,000.00 and > 5,000.00 MZM. Therefore, it is composed of two dummy variables: $R_{1}$ which takes the value of 1 if household income is within the range of 500.00-2,500.00 MZM and 0 otherwise, and $R_{2}$ if household income is within the range of 2,501.00-5,000.00 MZM and 0 otherwise. The category of households with income higher than 5,000.00 MZM is used as reference;

(3) The main sources of water $\left(n_{3}\right)$, which is composed of the following categories: river, borehole, collective tap and canalized water. Therefore, it is composed of three dummy variables: $F_{1}$ which is equal to 1 if the main source of water is a river and 0 otherwise, $F_{2}$ which is equal to 1 if the main source of water is borehole and 0 otherwise, and $F_{3}$ which is equal to 1 if the main source of water is collective tap and 0 otherwise;

(4) The number of household member involved in water collection $\left(n_{4}\right)$;

(5) The household water consumption $\left(n_{5}\right.$, $\left.\mathrm{m}^{3} / \mathrm{month}\right)$. The household water consumption is computed as Eq. (6):

Household water consumption $\left(\mathrm{m}^{3} /\right.$ month $)=$ the volume of water used per day $\times 30$

(6) The time spent to fetch water $\left(n_{6} ; \mathrm{min}\right)$;

(7) The number of containers used by the household per trip $\left(n_{7}\right)$;

(8) The volume of the containers used to collect water $\left(n_{8}\right)$ with two categories: containers with capacity for $20 \mathrm{~L}$ and containers with capacity higher than $20 \mathrm{~L}$. This variable takes the value of 1 if the household uses containers with capacity for $20 \mathrm{~L}$ and 0 otherwise;

(9) The opportunity cost per trip $\left(n_{9}\right)$. Following Banda et al. [25], the opportunity cost is estimated as the maximal rate paid for agricultural activities in the community. It is important to note that water collection involves males, females and children in
Sabié. Banda et al. [25] suggested that opportunity cost should be $50 \%, 25 \%$ and $12.5 \%$ of the maximal rate paid in agricultural activities ${ }^{3}$ for male, female and children, respectively. Therefore, in this study, the opportunity cost was computed as Eq. (7):

Opportunity cost $=(n m \times 0.5)+(n f \times 0.25)$

$$
+(n c \times 0.125)
$$

where, $n m$ is the number of the adult household males involved in water collection, $n f$ is the number of adult household females involved in water collection and $n c$ is the number of children in the household involved in water collection.

Thus, the functional form of the empirical model in Eq. (5) can be expressed as Eq. (8):

$$
\begin{aligned}
\log Y_{i j}= & \beta_{0}+\beta_{1} \cdot \log n_{1}+\beta_{2} \cdot \log n_{6}+\beta_{3} \cdot \log \cdot n_{4}+ \\
& \beta_{4} \cdot \log n_{8}+\beta_{5} \cdot \log n_{7}+\beta_{6} \cdot \log n_{9}+\beta_{7} \cdot \log n_{5} \\
& +\beta_{8} F_{1}+\beta_{9} F_{2}+\beta_{10} F_{3}+\beta_{11} R_{1}+\beta_{12} R_{2}+\mu
\end{aligned}
$$

\subsection{Data Collection and Analysis}

The data were collected by two semi-structured questionnaires, one for crop producers and another one for households. Two sample sizes (one for crop producers and the other for the households) were calculated using the following Eq. (9) as suggested by Gil [26]:

$$
n=\frac{N \times Z_{c}^{2} p q}{\varepsilon^{2}(N-1)+Z_{c}^{2} p q}
$$

where, $n$ represents the sample size, $Z$ is the level of confidence ( $5 \%$ in this study), $p$ is the proportion at which the phenomenon occurs (50\% in this study), $q$ is (1-p), $N$ is the target population size and $\varepsilon^{2}$ is the allowed error (5\% for water demand for irrigation and $9 \%$ for water demand for domestic use). From a list of 79 crop producers, a sample size of 66 producers was drawn and from a list of 1,145 households, a sample size of 110 households was drawn. The respondents were selected randomly using the list previously produced by the researchers. The data were analyzed

\footnotetext{
${ }^{3}$ The maximal rate paid for agricultural activities in Sabié during the study period was $100 \mathrm{MZM}$.
} 
using STATA and Eq. (3) was tested for normality, heteroskedasticity, autocorrelation and multicollinearity using the tests of Jarque Bera, White, Breusch-Gogfrey and Durbin Waston, respectively. The model in Eq. (8) follows Poisson distribution according to Wooldridge, which is cited by Farolfi et al. [17]. In this type of models, it is important to test for the dispersion of the data. Therefore, a chi-square test was used to test the data dispersion.

\section{Results and Discussion}

\subsection{Factors Determining Water Demand for Irrigation}

As described in data analysis, misspecification tests were conducted in the model as Eq. (3). The misspecification test results revealed the absence of heterocedasticity, multicolinearity and serial correlation at $5 \%$ level of significance. The normality assumption was also found to be holding at 5\% level of significance. These results reveal no violation of the assumptions of the model. Table 1 presents the results of the model.

The results indicated that the majority of the included variables are not statistically significant. However, the included variables explained the variation of water demand for irrigation by $97.91 \%$. These results show that the duration of irrigation is crucial factor affecting the sustainability of irrigation water management. Specifically, the results show that with an increase in $1 \mathrm{~h}$ of irrigation time, the demand for irrigation water increases by $362.04 \mathrm{~m}^{3} / \mathrm{month}$, and with an increase on one irrigation during a week, the demand for irrigation water increases by $1,065.61$ $\mathrm{m}^{3} /$ month. In order to reduce the duration of irrigation time, it is important in efficient irrigation systems which allow effective use of the water by the crop and reduce water runoff. However, the irrigation system used in Sabié is old and it is associated with high level of runoff which contributes to an increase in duration of irrigation time. Additionally, the lack of water tariffs might increase the duration of irrigation time, as producers do not value water, and therefore the introduction of water tariffs might contribute to sustainable management of irrigation water.

\subsection{Factors Determining Water Demand for Domestic} Use

Table 2 presents the results of the model of water demand for domestic use. As described in data analysis section, one of the assumptions of model

Table 1 Results of water demand for irrigation.

\begin{tabular}{lll}
\hline Independent variables & Coefficient & $P>t$ \\
\hline Irrigated area (ha) & -6.77 & 0.237 \\
$\begin{array}{l}\text { Duration of each } \\
\text { irrigation (h) }\end{array}$ & 362.04 & $0.00^{* * *}$ \\
Number of irrigations per & $1,065.61$ & $0.00^{* * *}$ \\
week & -36.07 & 0.57 \\
Type of irrigation & -16.07 & 0.89 \\
Production system & 0.51 & 0.99 \\
$D_{1}$ & -15.65 & 0.17 \\
$D_{2}$ & 10.81 & 0.85 \\
$D_{3}$ & -15.96 & 0.75 \\
$D_{4}$ & -68.37 & 0.16 \\
$D_{5}$ & $-2,091.89$ & $0.00^{* * *}$ \\
Constant &
\end{tabular}

*** significant at $1 \%$ level. Dependent variable is the quantity demanded of irrigation water $\left(\mathrm{m}^{3} / \mathrm{s}\right) . P>t$ is a $P$ value from $t$ scored calculator (normal distribution).

Table 2 Results of water demand for domestic use.

\begin{tabular}{lll}
\hline Independent variables & Coefficient & $P>z$ \\
\hline $\begin{array}{l}\text { Number of household } \\
\text { member }\end{array}$ & 0.009 & 0.685 \\
$\begin{array}{l}\text { Time spent to fetch water } \\
\text { (min) }\end{array}$ & -0.003 & $0.005^{* * *}$ \\
$\begin{array}{l}\text { Number of household } \\
\text { member involved in water }\end{array}$ & -0.236 & $0.000^{* * *}$ \\
collection & & \\
$\begin{array}{l}\text { Volume of the containers } \\
\text { used to collect water }\end{array}$ & -0.208 & $0.010^{* *}$ \\
$\begin{array}{l}\text { Number of containers used } \\
\text { by the household per trip }\end{array}$ & -0.076 & $0.004 * * *$ \\
$\begin{array}{l}\text { Opportunity cost per trip } \\
\text { Household water }\end{array}$ & 0.005 & 0.653 \\
consumption (m ${ }^{3} /$ month) & 0.001 & $0.002 * * *$ \\
$F_{1}$ & 0.446 & $0.014 * *$ \\
$F_{2}$ & 0.569 & $0.004 * * *$ \\
$F_{3}$ & 0.487 & $0.013 * *$ \\
$R_{1}$ & 0.346 & 0.182 \\
$R_{2}$ & -0.062 & 0.528 \\
Constant & 0.685 & $0.001 * * *$ \\
\hline$* *$ and $* * *$ significant & $5 \%$ and $1 \%$, & respectively. The \\
dependent variable is the number of trips to fetch water. $P>z$ \\
is a $P$ value from $z$-scored calculator (Poisson distribution).
\end{tabular}


presented in Eq. (5) is no dispersion of the data. The results of the test revealed that there is no evidence of dispersion of the data, indicating that the model follows the Poisson distribution.

The results show that water demand for domestic use is determined by time spent for water collection, number of household members involved in water collection, the volumes of the containers used to collect water, the number of containers used to collect water, household consumption of water, as well as the main source of water (river $-F_{1}$, boreholes $-F_{2}$ and public tap $-F_{3}$ ).

The sign of the variable time spent for water collection is negative as expected. This result shows that an increase in $1 \%$ of time spent in water collection decreases the number of trips by $0.3 \%$. Farolfi et al. [17] report that an increase in time spent to collect water tends to increase willingness to pay for services which provide water near to the household, such as the canalized water and public tap. The results in this study as well as in Ref. [17] are consistent with Sullivan [27], who states that households located far from water sources have high indices of water poverty.

The results also indicate that an increase in $1 \%$ in the number of household members involved in water collection decreases the number of the water collection trips by $0.23 \%$. Although the coefficient was not statistically significant in their study, Banda et al. [25] also found similar result. The coefficient of the volume of the container is positive, indicating that households using containers of $20 \mathrm{~L}$ tend to have lower number of trips compared to the families using containers with capacity higher than $20 \mathrm{~L}$. This result seems to be erroneous, since the quantity of water collected increases with the increase of the capacity of the container. However, taking into account that in rural settings, water is also collected by youth, the ownership of low capacity containers might increase the involvement of youth in water collection and consequently decrease the number of the trips needed for water collection.

The coefficient of the variable number of containers used to collect water owned by the households is positive as expected, since the potential of collecting considerable amount of water increases with the increase of the number of containers used to collect water. However, it is necessary to note that this is possible if there is enough number of household members to be involved in water collection. Additionally, it is necessary to note that in rural settings in Africa, households have been using hand-cars as transportation mean to collect water, and this type of transportation mean can transport about 10 containers in one trip.

As expected, an increase in household water consumption tends to increase the number of the trips to collect water. Specifically, the results are revealing that an increase in $1 \%$ of household water consumption increases the number of the trips by $0.001 \%$. This result was also found by Banda et al. [25], who reported that an increase in household water consumption increases the number of trips by $4 \%$.

Regarding the main sources of water (river $-F_{1}$, boreholes $-F_{2}$ and public tap $-F_{3}$ ), the results show that households collecting water from these sources have higher number of trips compared to household collecting water from the canalized source. This result is expected as household having canalized water will not have trips for collecting water and consequently they save time for water collection, which they can allocate in other productive activities. This result reveals again the need for building water supply infrastructures near the homes of the households.

\section{Conclusions and Policy Implications}

Water demand for irrigation is mainly determined by the duration of irrigation (time spent for irrigation per day and the number of irrigations per week). The quantity demanded of irrigation water increases with an increase in duration of irrigation. Therefore, in order to improve the management of irrigation water 
in Sabié, it is necessary to improve the efficiency of irrigation systems aiming at limiting runoffs and reducing the duration of irrigation. Pricing water will help in changing the behavior of the producers, and thus water can be seen as valuable limited resource, rather than natural and unlimited resource. Although, dissemination of crop water requirements as well as appropriate technologies to irrigate different types of crops should be incorporated to extension messages in Sabié.

The water demand for domestic use is determined by the time spent for water collection, number of household members involved in water collection, the volumes of the containers used to collect water, the number of containers used to collect water, the quantity of water consumed by the household as well as the main source of water (river, boreholes and public tap). The results regarding the main sources of water (river $-F_{1}$, boreholes $-F_{2}$ and public tap $-F_{3}$ ) show that households collecting water from these sources have higher number of trips compared to household collecting water from the canalized source. These findings call for policy changes aiming at developing water supply infrastructures near the homes of the households. Water price mechanism might be used to collect revenues which can be used to build water supply infrastructure near the home of the households, so in this manner reducing the number of the trips to fetch water.

\section{References}

[1] UNESCO-WWAP. 2008. "Water for People, Water for Life." Accessed November 06, 2016. http://webworld.unesco.org/. (in Spanish)

[2] Seckler, D., Amarasinghe, U., Molden, D., Silva, R., and Barker, R. 1998. World Water Demand and Supply, 1990 to 2025: Scenarios and Issues. International Water Management Institute Research Report.

[3] Vas, A. C., and Zaag, P. V. 2003. "Sharing the Incomati Waters: Cooperation and Competition Balance." Technical Documents in Hydrology, UNESCO. Accessed May 11 , 2015. http://unesdoc.unesco.org/images/0013/001332/133297e.

[4] Martins, R., and Fortunato, A. 2009. "Water Demand for
Domestic Use in Portugal.” In Proceedings of the Second Coimbra Water Congress.

[5] Speelman, S., D'haese, M., Buysse, J., and D'haese, L. 2007. "Technical Efficiency of Water Use and Its Determinants, Study at Small Scale Irrigation Schemes in North-West Province, South Africa.” EAAE, Montpellier, France. Accessed May 15, 2015. http://ageconsearch.umn.edu/bitstream/7904/1/sp07sp01.

[6] Mahdi, N., Sghaier, M., and Bachta, M. S. 2009. "Technical Efficiency of Water Use in the Irrigated Private Schemes in Smar Watershed, South-Eastern Tunísia." In Technological Perspectives for Rational Use of Water Resources in the Mediterranean Region. Bari: CIHEAM, 289-300.

[7] Chebil, A., Frija, A., and Abdelkafi, B. 2012. "Irrigation Water Use Efficiency in Collective Irrigated Schemes of Tunisia: Determinants and Potential Irrigation Cost Reduction.” Agricultural Economics Review 13 (1): 10.

[8] Chebil, A., Abbas, K., and Frija, A. 2014. "Water Use Efficiency in Irrigated Wheat Production Systems in Central Tunisia: A Stochastic Data Envelopment Approach." Journal of Agricultural Science 6 (2): 63.

[9] Nauges, C., and Whittington, D. 2010. "Estimation of Water Demand in Developing Countries: An Overview." World Bank Research Observer 25 (2): 263-94.

[10] Whittington, D., Mu, X. M., and Roche, R. 1990. "Calculating the Value of Time Spent Collecting Water: Some Estimates for Ukunda, Kenya." World Development 18 (2): 269-80.

[11] Whittington, D., Lauria, D. T., and Mu, X. M. 1991. "A Study of Water Vending and Willingness to Pay for Water in Onitsha, Nigeria." World Development 19 (2-3): 179-98.

[12] North, J. H., and Griffin, C. C. 1993. "Water Source as a Housing Characteristic: Hedonic Property Valuation and Willingness to Pay for Water." Water Resources Research 29 (7): 1923-9.

[13] Komives, K. 2003. "Infrastructure, Property Values and Housing Choice: An Application of Property Value Models in the Developing Country Context." Ph.D. thesis, Department of City and Regional Planning, University of North Carolina.

[14] Banda, B. M., Farolfi, S., and Hassan, R. M. 2007. "Estimating Water Demand for Domestic Use in Rural South Africa in Absence of Price Information." Water Policy 9 (5): 513-28.

[15] Whittington, D., Briscoe, J., Mu, X. M., and Barron, W. 1990. "Estimating the Willingness to Pay for Water Services in Developing Countries: A Case Study of the Use of Contingent Valuation Surveys in Southern Haiti." Economic Development and Cultural Change 38 (2): 293-311. 

Sabié Administrative Post, Moamba District, Mozambique

[16] Kanyota, P. 2008. "Water Value and Demand for Multiple Uses in the Rural Areas of South Africa: The Case of Ga-Sekororo.” M.Sc. thesis, Pretoria University.

[17] Farolfi, S., Mabugu, R., and Ntshingila, S. 2007. "Domestic Water Uses and Values in Swaziland: A Contingent Valuation Analysis." Agrekon 46 (1): $157-70$.

[18] Juízo, D., Souto, M., and Matsinhe, N. 2012. "Human Resource Capacity Gap Assessment (CapWASH)." The Mozambican Case, Salomon, Lda, Maputo, Mozambique. Accessed May 23, 2015. http://www.nepad.org/ sites/default/files/documents/files/CountryWaterResource Report-MozambiqueFinal1.

[19] Magaia, E. 2009. Institutional Arrangement for Water Management in the Limpopo River Basin: The Case of Mozambique. A Report of WaterNet.

[20] DNA. 1999. Water Resources of Mozambique: Synopsis 1999. Ministry of Public Works and Housing, Cooperation Portugal-Mozambique.

[21] Chilundo, M., Munguambe, P., and Massingue, F. 2010. Watershed Management in Mozambique: Experiences of the Establishment of the Basins committees of Rovuma, Licungo, Zambeze and Umbeluzi. South Africa: Global Water Partnership.
[22] Munguambe, P., Chilundo, M., and Massingue, F. 2010. "The IWRM Planning Process: Mozambique, Achievements, Lessons and Challengs." Global Water Partnership, South Africa. Accessed June 21, 2015. http://www.gwp.org/Global/GWP-SAf\%20Files/IWRM $\%$ 20Planning\%20Process\%20(Mozambique).pdf.

[23] Ayana, M., Teklay, G., Abate, M., Eshetu, F., and Mada, M. 2015. "Irrigation Water Pricing in Awash River Basin of Ethiopia: Evaluation of Its Impact on Scheme-Level Irrigation Performances and Willingness to Pay." African Journal Agricultural Research 10 (6): 554-65.

[24] Luís, J. 2012. "Dancor Training Center." MÓDULE I, PUMPS. Accessed February 20, 2015. www.dancor.com.br.

[25] Banda, B. M., Farolfi, S., and Hassan, R. M. 2006. "Determinants of Quality and Quantity Values of Water for Domestic Uses in the Steelpoort Sub-basin: A Contingent Valuation Approach." In Water Governance for Sustainable Development, edited by Perret, S., Farolfi, S., and Hassan, R. M. London: Earthscan, 167-88.

[26] Gil, A. C., 2007. Methods and Techniques for Social Research, 5th ed.. São Paulo: Atlas.

[27] Sullivan, C. 2002. "Calculating a Water Poverty Index." World Development 30 (7): 1195-210. 